\title{
A METHOD TO REDUCE LARGE NUMBER OF CONCORDANCES.
}

\author{
Maria Pozzi, Javier Becerra, Jaime Rangel, Luis Fernando Lara. \\ Diccionario del Español de México. \\ El Colegio de México \\ Camino al Ajusco \#20 México 20,D.F. \\ MEXICO
}

\section{Summary}

In order to help to solve the problem of analysing large number of concordances of a given word ' $W$ ', the 'Diccionario del Español de México! (DEM), has implemented a programme that

i) Reduces this number, as to obtain the maximum possible information with the minimum number of concordances to be handled.

ii) Sortes and rearranges the output so that similar concordances are printed out together.

This was done by comparing up to four words to the left and to the right of word $w$, through the whole set of concordances, associating toge ther those which were repeated in a particular context. Once knowing this, some significant concordances were selected to be printed out, and the rest was discarded.

\section{Introduction}

In the composition of a dictionary, those involved in the definition of each word have to study very consciously its set of concordances, so that no meaning or use is missed.

there are, of course, some difficulties since on one hand, the sample is never large enough as to insure the occurrence of all the different meanings and uses of every word to be defined. This problem is solved by consulting other dictionaries and expertees on the particular subject.

On the other hand, there are words having a very large number of occurrences, making their analysis a very difficult task, since it is not possible to have present in mind everything that is being analysed. At first thought this could be solved by taking at random a smaller number of concordances; however, when reducing in this way, one is about to loose the grammaticàt and semantic information contained in all those concordances to be taken away; hence a method had to be implemented as to attain the maximum possible information.

In order to solve this problem, the DEM presents a method whose aim is to obtain optimal information with the minimum number of concordances to be handled.

This method consists of, for each concordance to analyse and compare four words to the left and to the right of word $W$ together with their grammatical category associated; and establishing which one of them is identical to which other in a particular context: A tree structure is generated.

Having known this, it is proceeded to reduce the number, by selecting some of them considered to be representatives.

\section{I Preliminary Requirements}

Our sample (Corpus del Español Mexicano Contemporáneo: (EMC), consists of 1,973,151 occurrences, resulting in 65,200 different types, ${ }^{1}$ whose frequency vary from 1 to $68,252 .{ }^{2}$

Some preiliminary work has been done consisting in the automatic labeling of each and every word of the corpus with its grammatical category, ${ }^{2}$ in which from the total number of occurrences, 1,083,945 were automatically solved, and 
the rest had to be solved by hand, then the computer was fed with the results, obtaining in this form, the complete sample labelled. We took advantage of this work, since otherwise it would have been impossible to try to reduce the number of concordances in terms of the same grammatical category.

Next, was to implement a programme that produ ces, for any given word, its set of concordances; each word stating its own grammatical category. This is stored in a file called CONCUERDA, and it is organized in the following way:

Every concordance has three lines, each one of them consisting of:

- 6 characters (nnnnnn) reserved for the number of occurrence.

- 12 characters (tttppp111) reserved for the register of that line, according to the original text, and stating text code, page and line.

- 72 characters reserved for the actual text

- 18 characters for the label of each word of the line, stating the grammatical category code. The first two characters indicate the number of words in the line.

Figure number 1 shows part of file CONCUERDA and its organization.

\section{The Algorithm}

\subsection{Association of the $i$-Concordance to table ORDENA.}

For each concordance, a table ORDENA is associated in the following way:

- The word in question is located in the middle line and associated to ORDENA(5)

- Four words are selected to the right and to the left of $W$, since they are supposed to be carrying the most significant grammatical and semantic information about the word $W^{3}$ We took this idea from the Centre du Trésor de la Langue française"s work concerning to the treatment of binary groupes
- Each of the next four words to the right of W will take its place in $0_{j+1}$ if and only if

$w_{5+i} \in 0_{5+i}$ and $\not$ punctuation mark $p_{j}$ such that

$w_{5+i-1} \quad p_{i} w_{5+i} \quad$ and $p_{j} \in\{., ;: i ? i\}$

as they are considered to break up the continuity of a context.

- In similar way, the words to the left of $w$ are associated to their place in ORDENA.

Figure No. 2 shows how to construct table ORDENA from a given concordance.

\subsection{Generation of a Tree Structure starting from ORDENA.}

Once obtained this set of up to nine words, it is proceeded to construct a tree structure for the words to the right of $W$ and one for the words to the left of $w$.

It will only be described here the construction of the right branch of the tree. The left is generated immediately after, though in symmetric form:

- The tree has a root node which is the word $w$ itself, and has five levels, being the root in leve1 5 .

- A direct descendant of a node $w_{j}$ is given by the word $w_{j}$ such that $w_{j} w_{j}$ are adjascent, i.e. if $w_{i} \in$ ORDENA $_{i}$ and $w_{j} \in \mathrm{ORDENA}_{i+1}$ then

$w_{j}$ is a direct descendant of $w_{j}$.

- The label of each node consists of:

- Word $w$ associated.

- Its grammatical category.

- Its frequency. And pointers to:

- Direct ascendant.

- First direct descendant.

- Next node whose direct ascendant is the same as the one of itself.

- Another file called CONCORD, where it is stored the number of the concordance or concordances where that word in that 


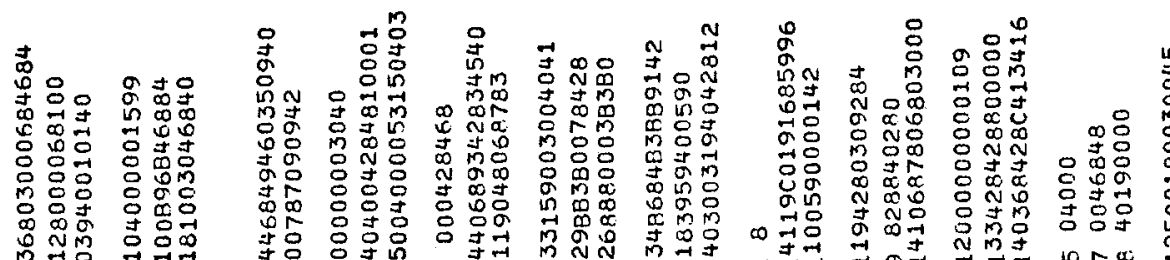

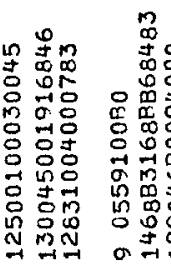

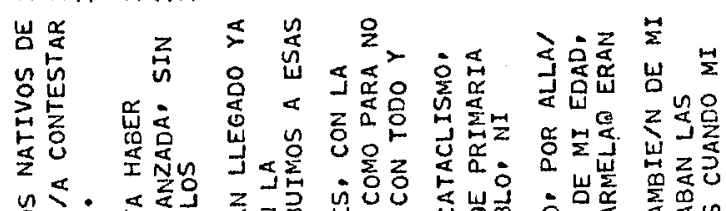

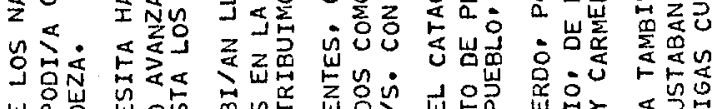

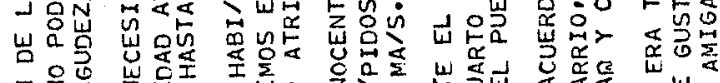

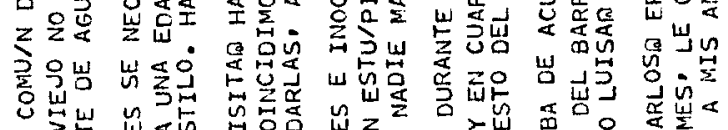

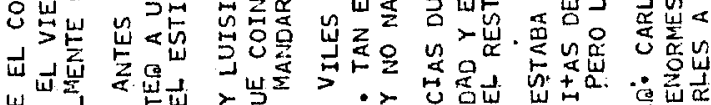

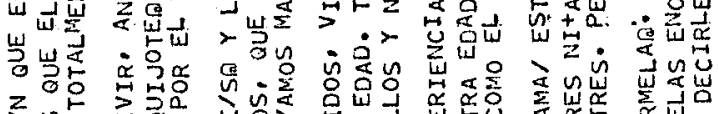

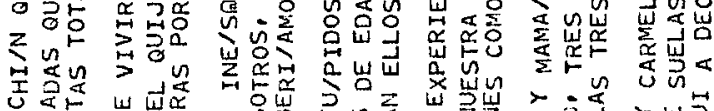

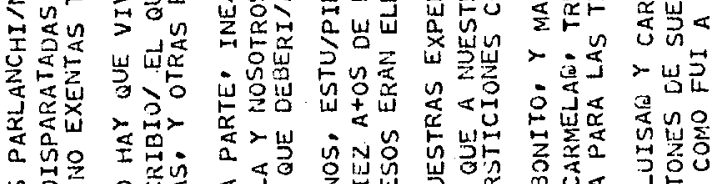

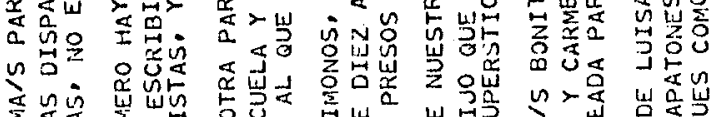

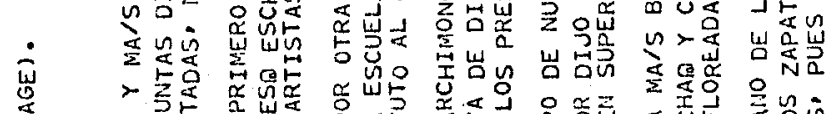

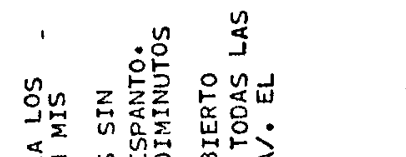

等

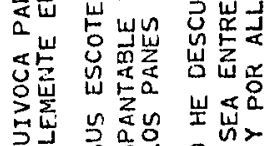

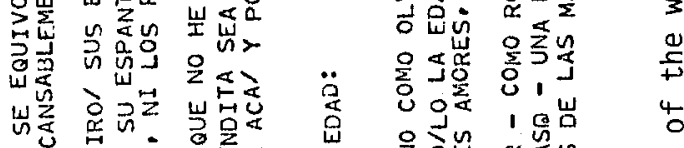

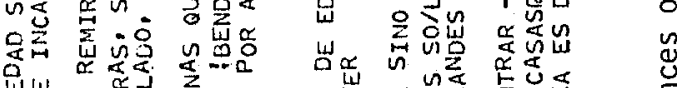

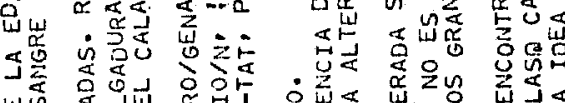

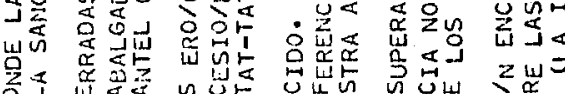

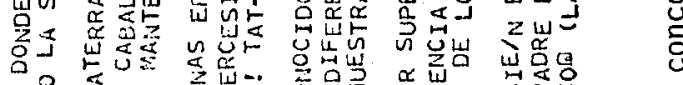

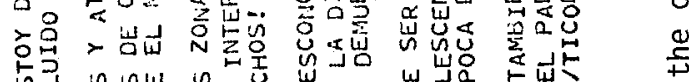

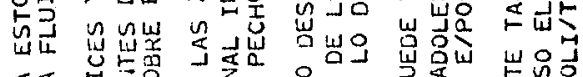

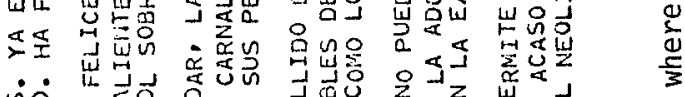
ن웅

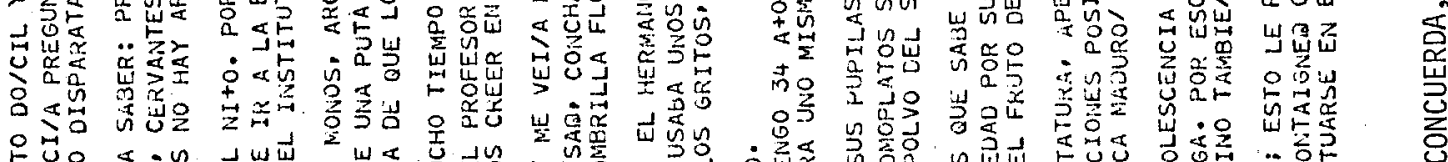

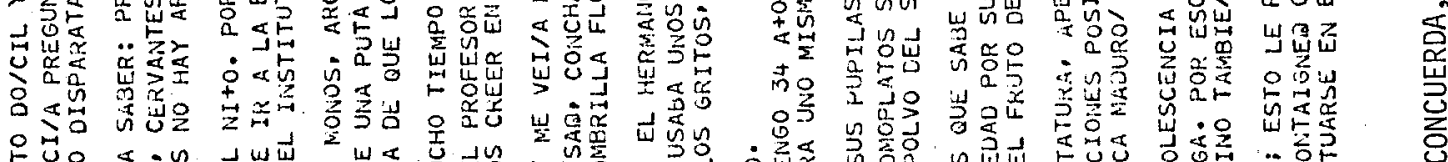

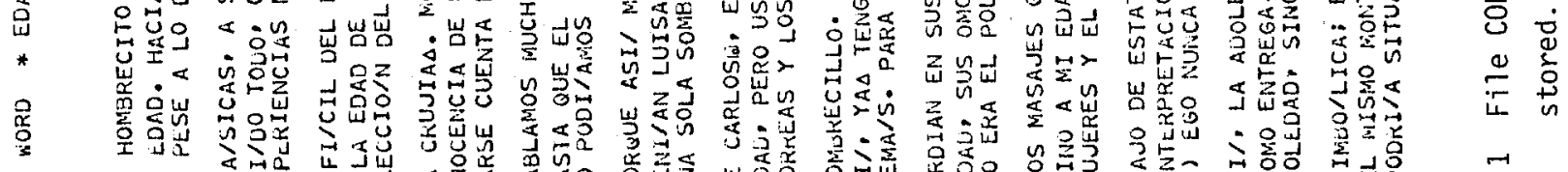

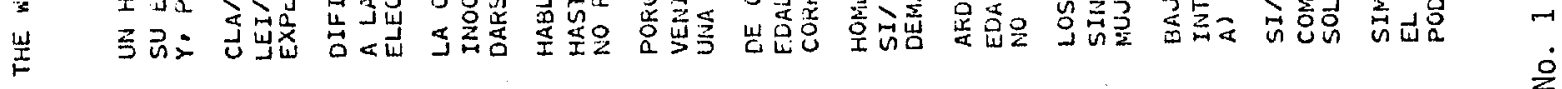

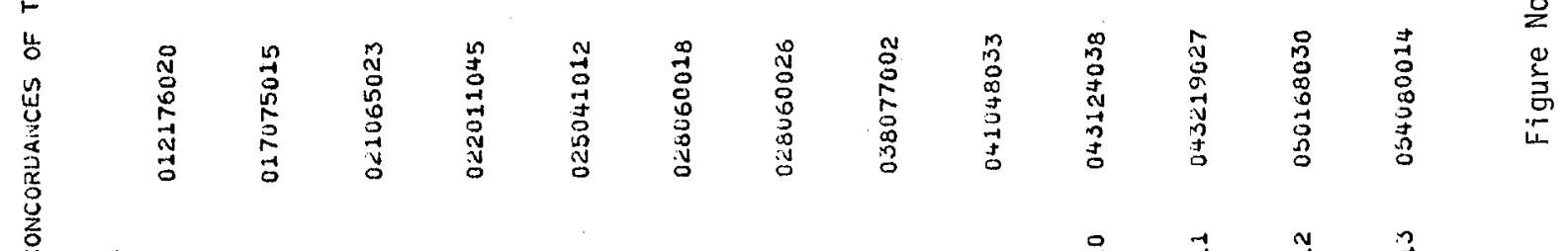


particular context came from, making in this way possible the retrieval operation.

-A node has as many branches as different words are found to be direct descendants to that word, with the same grammatical category through the whole set of concordances.
The process repeats itself until the last concordance has been processed.

Figure No. 3 shows, for a set of 14 concordances, the left and right trees generated.

\section{ORDENA[I:9]}

\begin{tabular}{|l|l|}
\hline NO & 1 \\
\hline$E S$ & 9 \\
\hline SOLO & 1 \\
\hline LA & 6 \\
\hline EDAD & 8 \\
\hline$D E$ & 4 \\
\hline LA & 6 \\
\hline SOLEDAD & 8 \\
\hline & \\
\hline & \\
\hline
\end{tabular}

Figure No. 2 Table ORDENA is obtained from a given concordance. Note that ORDENA(9) is void, since there is a comma (,) after the word 'soledad' 
$342 \geq 5 \div 019$

$34535 j 029$
SUCEOI/A AL!A/ POR EL A+O DE 18.31, CUANDO DON PEFED TENI/A UNOS 55 ATOS DE LDAD Y MUCHOS RI TONES. AU/N. TUVO UN IMITADOR NOTABLE, QUE FUE UN BANDERTLLERO LIAMADO ANTONIOA GONZA/LEZG EL" OFIZAGË+O, QUIEN DIO A

AHORA, LA EMPRESA QUE LA TIEN RLNTADN, SE ESTAI GASTMNDO UN DINERAL EN 1310011.591684 ESTE SERIAL, BUSCANDO NUEVOS VALORES, MISMOS QUE - HASTA QLIE SU EDAD SE 12:8011:34J285 LOS PERMITA - NO HABRA/N DE SALIF DE ENTRL LOS NI+OS TOREIIOS.

CONSEGUIR DINERO PARA SACMT AOELANTE LA FINDACIO/N. PRIMERO HABLO/ EL SE $+O R$ CURA QUE ENTOKCES NO TENI/A NI TERTNIA IOS DE CDAD. LUEGO DON TOMA/SA SA/NCHEZO (ESTE SI/ VIEJO Y COLLDO) FROPUSO COLECTAS Y RIFAS.

CABAL!OS. 10 TAS JOSE/A HABI/A ME,OIO MILLAR DE HOMBRES IIN EDAD DE TOMAR LAS ARMAS E IRSE A LA GUEFINA, PEFIO NO TODOS SE SINTIERON CON ANIIMIOS DE

CASADOS Y TENI/ANN HIJOS. LOS MA/S ERAN JO/VENES IN LL VERDOR DE LA EOAD, DE 16 A 30 ATOS. CON ALGUNA DESTRE?A EN ILL MANEJODE: AFMAS Y CABALI..OS Y SIN DISCIFLINA MILITAR. 50340 ?
$139.4684 C \leq 0 B 900$ $1: 59: 0404: 68$ ]

$100: \cdots \quad \therefore 96$ $1380,1: 238: 4320$ $11.8 \div 219300 \cdot 13 !$

$1348600843433 \div 96$ 1483040.31 .59494

$13859800,468+60$

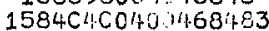

ENCUBIERTOS DEL DIABLO, O AL MENOS DO/CILES INSTRLMENTOS DE SUS AVIESO: 1 i.078370; 428 DESIGNIOS, LA BEATA IMAGEN DE LA EDAD DE ORO REDIVIVA SE TRANSMUTO/, AL 130083460431397 CONJURO DEL DES:NGATO, EN EOAD DE HIER:OO EN QUE DOMINABA LA CRECIINTE 128784040406

DESIGNIOS, LA BEATÁ IMAGEN DE LA EDAD DE ORO FEDIVIVA SE TRANSMUTO/, AL 13001.46840.597

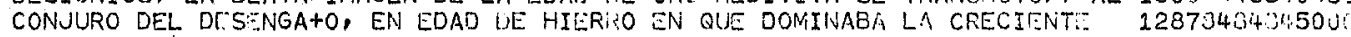
CONVICCIO/N DE QUE IESOS DESNUDOS HIJOS DEL OCE/ANO FORMABMN PARTE DEL 1.04028,7C9J7

INDI/GENAS, COMO ES AU/N, EN PARTE ESTL/RIL, SINO QUE REALIZARI/A SU 110:9:40:3:2 PROGKESIVA EDUCACIO/N EN LA IDOLESCINNCIA Y HASTA EN LA EDNO ADULTA'. $13.8040 \% 34 \% 68 \%$

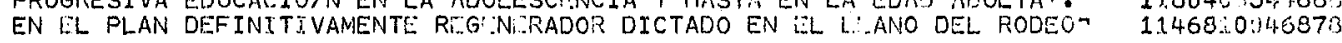

JURA/IS Y YO PIERDO UN ALUMNO. 6935908 NO EXISTE I:L DESIO DE UN TRABAJO MANUAL PEGADO. ESTO ES:XACTO EN LA 1410684080.59J43

PERCIBIR SUS CUALIDAOES TANTO MATERIALES COMO FUNCIONALES, ASI/ COMO $90283: 1$

SU CONVENIENCIA RESPECTO A LA EDAD DE QUIEN LA IBA A USAR: OBSERVO/ SU 1428146845594092 CONTENIDO Y MANEJO. SE DIO CUENTA DE SU PESO Y RESTETENCIA ASI/ COMO DE 1483059842030104

DESARIOLLO DE LA IMAGINACIO/N CREADORA YALGUNAS HIBILIDALES PARA OPERAI: $9400:$

CON HERI AMIENTAS SENCILI.AS; ES, ADEMA/S, ADECUADO A L/ EDAD DE MI HIJO. 124017918468423 INSTRUCCIONES. LA PRESENTE :-SCALA CONTIENE OCHO ASPECTOS ESIINCIALES LN $90.1 .: 4$

LE ES FA/CIL HACER AMISTADES: IME IES BASTANTE FM/CIL HACERLAS Y ME $125901.59: 35$ GUSTA QUE SEAN ALEGR:S, D\% MI EDAI Y TENGAN UI IIIVEL CULTURAL POCO MA/S 14909842839630.1 $O$ MENOS COMO EL MI/0.1 Y FRENTE A UN GRUPO. DE NI+OS: ME DA GUSTO VER 1630.10533468485930

TERMINAR LA CAR: EI A DE MEDICINA. 50.4

CASO 2. ALUMNO DE 19 A 05 DE LOAO; SEXO MASCULINO. PROCEDENTL: DL: LA $130 C 84 C 0400.4$ ESCUELA- DE ARQUITECTURA DE UNA UNIVERSIDAD DE PROVINCIA.

IDENTIFICA CON LA PLENA REILIJACIO/N DE LAS ATPRACIONES QUE LL HONGRE $1.940: 1$ if 1 68

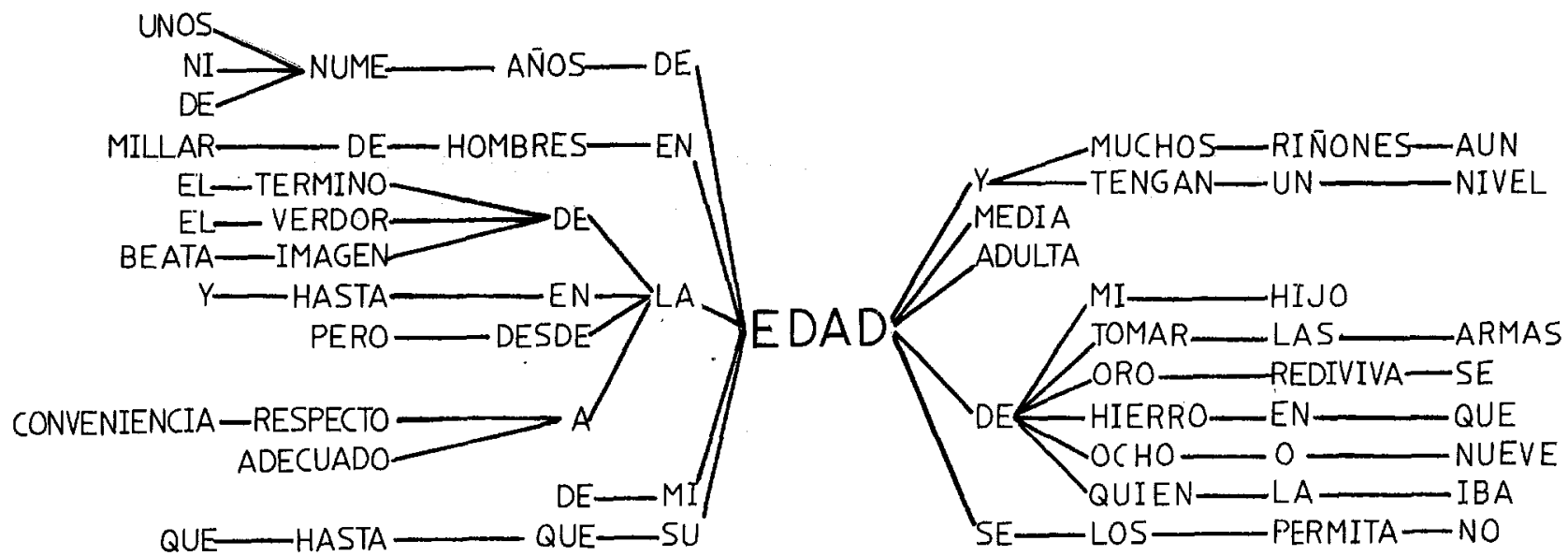

Figure No. 3 Left and right trees generated from a set of 14 concordances. 
3.3 The algorithm to select significant concordances.

once the tree is fully constructed it is proceeded to make the actual reduction.

There are some facts to be considered beforehand:

- The more words repeated exactiy in the same context, the greater is the probability that the meaning of the word $W$ in that context is the same.

- A set of words repeated a sma11 number of times may be more significant than another one repeated a larger number of times since there are not so many different meanings or grammatical functions of a word 4 followed by the sa me set of words.

Next, it will be described the proced ure:

In order to analyse the tree, a leftmost path is followed.

- A 6th level branch of the tree is first analysed (Remember that the root is in level 5, and that the tree to the right of $W$ is being analysed). If the frequency is greater than 1 , then its leftmost direct descendant is analysed in the same way.

- If a 9th level rode is reached in this form, and the frequency $n>1$, it means that the words $W$ followed by these four words ocurred a times in $n$ different concordances. As it was said before there is a good probability that the meaning of the word $y$ in this partictlar context is the same in all of the $n$ concordances: hence, by talking only one or two of them, by means of a random function, we obtain a significant concordance, and the $(n-1)$ or $(n-2)$ left can be safely omited from the $f i$ nal output.
- If at same intermediate level it is found that the frequency of the word associated to that mode is 1 , then the analysis of such branch would have to be stopped; however, it was thought that a possible way to reduce was not by identical words but by the same grammatical category. It is proceeded then to find all direct descendants of its own direct ascendant with the same frequency and grammatical category, and then the number of these concordances is reduced.

It is clear that the process takes into account that as the level of reduction is closer to 5 , then the context is less significant; hence a larger number of concordances have to be chosen to mantain the required quality information.

After some study and many trials it was empirically decided by our team of linguists* that a reasonable pattern of reduction was the following:

- If the level of reduction is 4 or 6 and the frequency $F \leqslant 30$ then the number of concordances selected $Q$ would be $Q=F / / 2+1$ and $Q=F / / 4$ if $F>30$.

- If level is 7 or 3 then

$Q=F / / 3+1$ for $F \leqslant 50$

$Q=F / / 5$ for $F>50$

- If leve? is 8 or 2 then

$Q=F / / 4+1$ for $F \leqslant 70$

$Q=F / / 7$ for $F>70$

Finally, if level is 9 or 1 then

$Q=F / / 5+1$ for $F \leqslant 50$

$Q=F / / 10+1$ for $F>50$

* At this point, we would like to thank in particular to Paulette Levy for her valuable discussions and interesting suggestions. 
It has to be mentioned here, that this pattern of reduction may be changed according to the word analysed, as to obtain the best results each time.

When it is already known the number of concordances that will be chosen ( $Q$ out of F) it is proceeded to select them again, by means of a random function, and each one of them is marked as such, to avoid any one of them be selected twice or more times.

3.4 output.

The final output is presented indicating the group of words repeated the grammatical category of the last word when applicable - and the frequency. Next, the $Q$ concordances chosen are 1 is ted below.

Figure No 4 shows the form in which the output is presented.

\section{The Computational system.}

The system was implemented in the University of Norway version of ALGOL 60 NUALGOL for a UNIVAC 1106 computer of the "Centro de Procesamiento Arturo Rosenblueth" of the Secretaria de Educación Pública (Ministry of Education), with $262 \mathrm{~K}$ words of 36 bites of central memory and $8,000,000$ of characters in disc.

\subsection{Data Storage.}

We made use of 3 files:

a) File CONCUERDA, where the whole set of concordances of the word $W$ was stored, and it was described above.

b) Files ARBOL and CONCORD; these two files are supposed to contain the information obtained whilo generating the right and left trees.
ARBOL: Each node of the tree is stored in a line composed of 72 characters, distributed in the fo$110 w i n g$ way:

7 for its own address in file

ARBOL

1 for the level

24 for the word

2 for the grammatical category

3 for the length of the word

4 for the frequency

7 for the address of its direct

ascendant

7 for the address of the next $d i$ rect descendant of its own direct ascendant (i.e. like next brother) 7 for the address of the first direct descendant

4 for the number of direct descendants (i.e. No of branches emerging from it) and

6 for the address in file CONCORD where it is stored the number of the concordance where it comes from.

From the computational point of view, each one of the trees is generated in the following way:

- The root, whose node associated is the word $W$ is in a prefixed address, and it will be present in every concordance. This word is taken from ORDENA $(5)$

- The next word in ORDENA will be stored by means of a hash function, and it is decided to be the same node as one previously stored, if and only if the word, its grammatical category, level and direct ascendant are exactly the. same, in such case the frequency is aumented by one and in file CONCORD is stored the number of this concordance in addition to the previous one. 


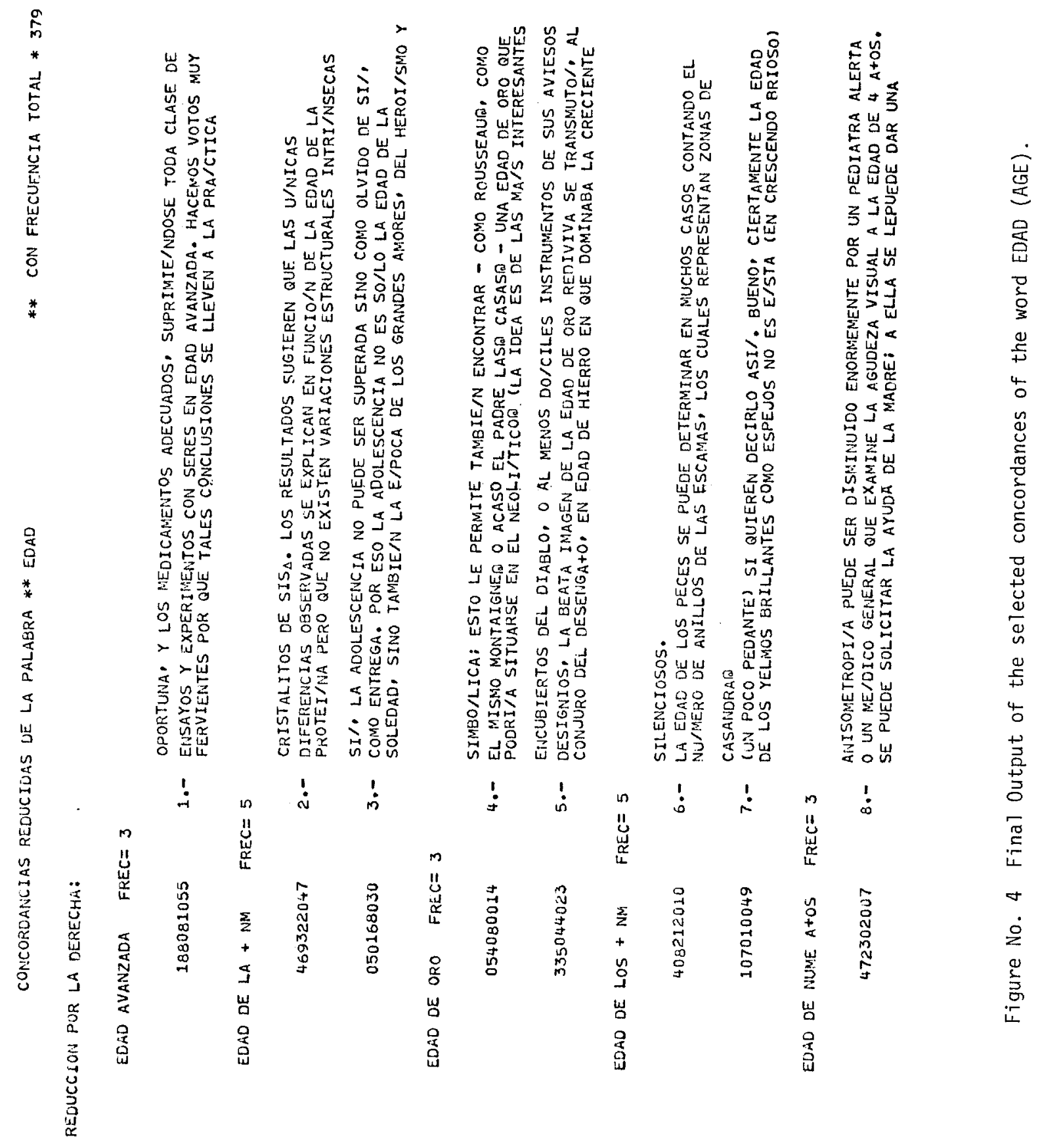


TREE STKUCTURE GENERATED FOR WORD *EDAD* (AGE).

\begin{tabular}{|c|c|}
\hline 31596 & $20 E$ \\
\hline $\begin{array}{l}31608 \\
31620\end{array}$ & $\begin{array}{l}3 Y \\
4 M I\end{array}$ \\
\hline 31632 & 2MOUERADAME NTE \\
\hline 31644 & 2PUES \\
\hline 32656 & $3 Y$ \\
\hline 31668 & $3 Y$ \\
\hline 31680 & $2 D E$ \\
\hline 31692 & $\begin{array}{l}2 \mathrm{CE} \\
350 / \mathrm{LO}\end{array}$ \\
\hline $\begin{array}{l}31716 \\
31728\end{array}$ & $\begin{array}{l}350 / L O \\
4 E S A\end{array}$ \\
\hline $\begin{array}{l}31740 \\
31752\end{array}$ & $\begin{array}{l}\text { 2ALGU/N } \\
\text { 2PROBABLEMENTE }\end{array}$ \\
\hline 31800 & $\begin{array}{l}\text { 2HROBABLEMENTE } \\
2 \text { CON }\end{array}$ \\
\hline 31812 & $2 \mathrm{CON}$ \\
\hline 31824 & $2 \mathrm{CON}$ \\
\hline 31836 & $4 S U$ \\
\hline 31848 & $4 T U$ \\
\hline 31860 & 4TAL. \\
\hline 31896 & 4POCA \\
\hline $\begin{array}{l}31908 \\
31920\end{array}$ & $\begin{array}{l}\text { 2INVERSAMENTE } \\
\text { IPALA }\end{array}$ \\
\hline 31932 & $3 A$ \\
\hline 31944 & $3 A$ \\
\hline 31956 & $3 A$ \\
\hline 31968 & $3 A$ \\
\hline 31980 & 3QUE \\
\hline 31992 & 4TODA \\
\hline 32004 & $3 \mathrm{~A}$ \\
\hline 32016 & 3QUE \\
\hline 32028 & $3 A$ \\
\hline 32040 & 3CIERTAMENTE \\
\hline 32052 & 4ESTA \\
\hline $\begin{array}{l}32064 \\
32076\end{array}$ & $\begin{array}{l}\text { 2POR } \\
4 \text { CUYA }\end{array}$ \\
\hline 32088 & $3 D E$ \\
\hline 32100 & $30 E$ \\
\hline 32112 & 3DE \\
\hline 32124 & 4OTRA \\
\hline 32136 & $30 E$ \\
\hline 32148 & $3 D E$ \\
\hline 32160 & ZHASTA \\
\hline 32172 & ZHASTA \\
\hline 32184 & $30 \mathrm{E}$ \\
\hline 32196 & 2CONFORME \\
\hline 32208 & 3EN \\
\hline 32220 & GYA \\
\hline 32232 & $3 E N$ \\
\hline 32244 & 3EN \\
\hline 32256 & 6140 \\
\hline 32263 & 4ESTE \\
\hline 32280 & $3 A$ \\
\hline 32292 & 3PERO \\
\hline 36304 & $3 A$ \\
\hline 32316 & 2LE \\
\hline 32328 & 3EXACTAMENTE \\
\hline 32340 & $3 A$ \\
\hline
\end{tabular}

\begin{tabular}{|c|c|c|c|c|c|c|}
\hline PR2 & 1 & 30936 & & & & 4647 \\
\hline $\mathrm{CO}$ & 1 & 32712 & 36576 & 36552 & 1 & 3228 \\
\hline$A \cup 2$ & 9 & & 33168 & 32100 & 4 & 69 \\
\hline$A V_{13}$ & 1 & 36360 & & & & 2046 \\
\hline $\mathrm{CO} 4$ & 1 & 32436 & & & & 3879 \\
\hline $\mathrm{COI}$ & 1 & 34008 & 32496 & 37344 & 1 & 3987 \\
\hline $\mathrm{COI}$ & $\tilde{i}$ & 32688 & & 5232 & $i$ & 4149 \\
\hline PR2 & 2 & 33372 & & & & 4674 \\
\hline PR2 & $\overline{1}$ & 31056 & & & & 4749 \\
\hline AVS & 1 & 34008 & 32208 & 34644 & 1 & 141 \\
\hline $\mathrm{AJ} 3$ & 5 & 12 & 31896 & 32232 & 4 & 507 \\
\hline $\begin{array}{l}A=6 \\
A \cup 13\end{array}$ & $\frac{2}{1}$ & $\begin{array}{l}36312 \\
31944\end{array}$ & 35028 & & & 563 \\
\hline PR3 & 1 & 32980 & 31920 & & & 219 \\
\hline FR3 & 1 & 35400 & & & & 633 \\
\hline PR3 & 1 & 35664 & 33192 & & & 1680 \\
\hline $\mathrm{AJ}_{2}$ & 16 & 12 & 34344 & 32088 & 6 & \\
\hline$A J_{2}$ & 2 & 12 & 31728 & 31116 & 2 & 498 \\
\hline$A \sqrt{ } 3$ & 1 & 12 & 32352 & 32280 & 1 & 2802 \\
\hline $\begin{array}{l}A \cup 4 \\
A \cup 12 \\
P R 4\end{array}$ & $\begin{array}{l}2 \\
1 \\
1\end{array}$ & $\begin{array}{l}12 \\
32424 \\
31980\end{array}$ & $\begin{array}{l}32076 \\
32580\end{array}$ & 32148 & 1 & $\begin{array}{l}540 \\
1749 \\
2607\end{array}$ \\
\hline PRI & 10 & 34344 & 5556 & 5472 & 5 & 15 \\
\hline $\begin{array}{l}\text { PR } 1 \\
\text { PRI }\end{array}$ & $\begin{array}{l}25 \\
1\end{array}$ & $\begin{array}{l}34008 \\
32832\end{array}$ & 308 & $\begin{array}{l}3468 \\
31332\end{array}$ & $\begin{array}{l}20 \\
1\end{array}$ & $\begin{array}{l}27 \\
54\end{array}$ \\
\hline PRI & $i$ & 31620 & 32880 & 31560 & 1 & 114 \\
\hline $\cos$ & 2 & 34008 & 32112 & 318 & 2 & 216 \\
\hline$A \sqrt{4}$ & 1 & 12 & 32124 & 32532 & 1 & 366 \\
\hline $\begin{array}{l}\mathrm{PR} 1 \\
\mathrm{CO} 3\end{array}$ & $\begin{array}{l}2 \\
1\end{array}$ & $\begin{array}{l}31728 \\
31836\end{array}$ & $\begin{array}{l}36324 \\
32568\end{array}$ & $\begin{array}{l}35496 \\
32160\end{array}$ & 1 & $\begin{array}{l}537 \\
1128\end{array}$ \\
\hline PRI & $i$ & 33060 & & & & 1740 \\
\hline AV11 & 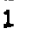 & 34008 & 35604 & & & 411 \\
\hline$A \sqrt{4}$ & 6 & 12 & 33252 & 32184 & 5 & 1980 \\
\hline PR3 & 2 & 30504 & & & & 2625 \\
\hline $\mathrm{AJ}_{4}$ & 1 & 12 & 32556 & & & 648 \\
\hline PR2 & 9 & 31836 & 32016 & 35256 & 8 & 6 \\
\hline$P^{\prime} R \overline{2}$ & 6 & 31620 & 31968 & 31344 & 4 & 72 \\
\hline PR2 & 21 & 34008 & 32040 & 37320 & 19 & 345 \\
\hline Au4 & 1 & 12 & 31848 & 32136 & 1 & 381 \\
\hline PR2 & 1 & 32124 & & 34524 & 1 & 334 \\
\hline PR2 & 2 & 31896 & & 30996 & 2 & 543 \\
\hline PR5 & 1 & 32016 & & & & 1131 \\
\hline PR5 & 1 & 32208 & 34836 & & & 1215 \\
\hline $\begin{array}{l}\text { PR2 } \\
\text { COB }\end{array}$ & 1 & $\begin{array}{l}32052 \\
35626\end{array}$ & 32304 & 35124 & 1 & $\begin{array}{l}1983 \\
2346\end{array}$ \\
\hline PR2 & 15 & 34008 & 31980 & 353 & 11 & 189 \\
\hline$A \vee 2$ & 2 & & & & 1 & \\
\hline PR2 & 1 & 31728 & 32004 & 35976 & 1 & 510 \\
\hline PR2 & 1 & 34344 & 32796 & 35892 & 1 & 1809 \\
\hline AV2 & 2 & 24 & 39264 & 37884 & 2 & 651 \\
\hline$A \sqrt{4}$ & 2 & 12 & 31860 & 36156 & $\overline{1}$ & 2787 \\
\hline PR1 & 1 & 31860 & & 36168 & 1 & 2805 \\
\hline $\mathrm{CO} 4$ & 2 & & 3160 & & & \\
\hline PR 1 & 2 & 32052 & & 36804 & 1 & \\
\hline PN2 & 1 & 36900 & & & & \\
\hline AV 11 & 1 & 34008 & 30468 & 36516 & 1 & 3165 \\
\hline PR1 & 1 & 31848 & & 5220 & 1 & 3192 \\
\hline
\end{tabular}

Figure No. 5 FiTe ARBOL, where the tree structure is generated. 
- 0therwise it will be a new rode.

Figure No 5 shows part of file ARBOL, EDAD ( $A G E$ ) is being processed.

\section{$V$ Results And Applications.}

The first results were very encouraging, since for those words with medium number of concordances - say up to 600 we were able to reduce the number between $30 \%$ and $40 \%$, according to the word in question.

No lost information was reported (by comparing the original set of concordances with the reduced version)

It is expected that for words with higher frequency, the method here des.. cribed will be more efficient.

However, from the computational point of view, there are still some difficulties, since the generation of each tree is very time consuming as the frequency of the word in question increases. Ue are still working to optimize it.

The most important application besides the original main objectives, is that by this method it is possible to find expressions and patterns of 1anguage repeated and used consistentiy.

\section{References}

1.- Roberto Ham Chande: Del 1 al 100 en Lexicografia, in Investigdeiones Linguisticas en Lexicografía, Jornadas 89 El Colegio de México, 1979

2. - Isabel Garcia Hidalgo: La Formalización del Analizador Gramatical de 1 DEM $y$

Luis Fernando Lara y Roberto Ham Chande: Base Estadistica del DEM in Investigaciones linguisticas en Lexicografia. Jornadas 89 El Colegio de Mêxico, 1979.

3. G.GorCy, R.Martin, J. Maucourt, Rvienney Francaise: Le Traitement des Groupes Binaries. Cahiers de Lexicologie. $17-1970-I I$ 